\title{
Illustrations and Tables
}

\section{FIGURES}

x. Muslim street vendor selling tobacco in Cotabato City $\quad 38$

2. Interior view of Campo Muslim 42

3. Datu Utu with his wife, Rajah Putri, and retinue, circa $1890 \quad 93$

4. Datu Piang with attendants, 19I4 95

5. Edward Kuder with his student Salipada Pendatun, 1927 I I I

6. Laborers unloading cargo at riverside landing I 26

7. Cotabato MNLF fighters, circa $1975 \quad 159$

8. Photograph commemorating the I95I visit of Maulana Mohammad Abdul Aleem Siddiqui to Cotabato $20 \mathrm{I}$

9. Wedding Procession near Campo Muslim 224

Io. Dayunday performance in Campo Muslim 225

\section{MAPS}

I. Cotabato and the Pulangi River System 26

2. Physiography of southwestern Mindanao 28

3. Three Present-Day Provinces of the Cotabato Basin 34

4. Campo Muslim 198

\section{TABLES}

r. Muslim and Non-Muslim Populations of Cotabato

2. Top Eight Vote-Getters for Mayor in Six Campo Muslim Precincts, I988 Municipal Election 
